\title{
VERIFICATION OF THE SYSTEMATIC POSITION OF CALIFORNIA BROME (Bromus carinatus Hook. AND Arn., Poaceae), cv. 'Broma', ON THE BASIS OF ANALYSIS OF ISSR MARKERS
}

\author{
Agnieszka Sutkowska \\ Department of Plant Breeding and Seed Science, University of Agriculture in Kraków \\ Łobzowska 24, 31-140 Kraków, Poland \\ e-mail: asutkowska@ur.krakow.pl
}

Received: 07.10.2011

\begin{abstract}
'Broma' is a grass cultivar belonging to the species Bromus carinatus. In the Lists of Agricultural Plant Varieties of the Research Centre for Cultivar Testing (COBORU), it is shown as Bromus willdenowii (= B. catharticus, B. unioloides) (List of Agricultural Plant Varieties 1989-2009), whereas already in 1984 Mirek demonstrated on the basis of morphological analysis that this was a different closely related species $-B$. carinatus.

The aim of the present study was to verify the species affiliation of cv. 'Broma'. The conducted analysis of ISSR molecular markers included representatives of cv. "Broma" as well as of $B$. carinatus and $B$. willdenowii.

The method used allowed the identification of molecular markers of the above-mentioned taxa. The numerical analysis of the obtained results suggests that cv. 'Broma' should be classified in the species $B$. carinatus, not $B$. willdenowii.
\end{abstract}

Key words: Bromus carinatus, Bromus willdenowii, cv. 'Broma', ISSR, molecular markers.

\section{INTRODUCTION}

The genus Bromus L. is one of the richest in species in the grass family (Poaceae) and for years it has been an object of great interest for evolutionists, taxonomists, and breeders. S te b bins (1981) divided it into seven groups at the rank of subgenus: Festucaria, Bromus, Stenobromus, Ceratochloa, Neobromus, Nevskiella, Boissiera. Numerous polyploids and hybrids found in this plant group create difficulties in determining the number of species. This problem largely relates to the subgenus Ceratochloa. Morphological and molecular studies of South American species have shown that it is nearly impossible to identify taxa in this group, in spite of the fact that in morphological terms the subgenus Ceratochloa is a well-defined taxon, clearly differing from the other subgenera of the genus Bromus (M a s s a et al. 2001, 2004). It comprises annual to perennial plants with spikelets strongly laterally flattened. The plants are characterized, among others, by a 3-5-veined lower glume and a 5-9-veined upper glume (M i r e k, 1984).

In Poland two species are found belonging to the subgenus Ceratochloa: B. willdenowii, classified as an ephemerophyte, and B. carinatus which was not recorded in Poland or in Europe until 1984, but already two years later it was recognised to be an ephemerophyte (Rostański and Sowa, 1986-1987) and subsequently classified as a kenophyte $(\mathrm{Z} \mathrm{a} \mathrm{j}$ ą $\mathrm{c}$ et al. 1998). The introduction of some varieties of this species into cultivation in Poland has undoubtedly contributed to its quick spread. In 1973 the cultivar 'Una' was included in COBORU's list of varieties, while in 1988 cv. 'Broma' derived from 'Una' (LORR, 1989).

From the very beginning, these cultivars were wrongly identified as B. unioloides or B. catharticus. These two synonyms are given as the species name, whereas $B$. willdenowii as a synonym (LORR 1973-2009). Mirek (1984) showed that the brome introduced into cultivation was not $B$. willdenowii $=$ $B$. unioloides, but $B$. carinatus. Due to this divergence, an attempt was made in the present study to verify the systematic affiliation of the cultivar 'Broma' using molecular methods for this purpose.

Bromus willdenowii Kunth. (syn.: B. catharticus Vahl, B. unioloides Kunth.) (rescue brome) is a perennial grass found in the wild only in South America, with the number of chromosomes $2 n=6 x=42$. M i r e k (1984) gives detailed morphological characteristics of 
this species, drawing attention to the fact that its lemma is awnless or rarely has a very short awn (1-2 mm long). He also points out its quite high variation, in particular as far as the hairiness of the lower glumes and their venation are concerned, and the production of cleistogamous flowers distinguished by shorter anthers. $B$. willdenowii is cultivated as a valuable fodder plant both in its native country and in different regions of Central and North America as well as in Europe (M i r e k, 1984). It is popular in livestock farming on account of its high fodder quality, productivity, and pasture persistence. This plant gives the best yields on fertile soils with low aluminium content. This species can be encountered along roads and on baulks (T s v e $1 \mathrm{ev}, 1970)$ as well as in other communities where it finds proper conditions for growth, particularly moisture conditions (B o r , 1970). It is a naturalised species in some European countries, while in Poland it is classified as an ephemeral synanthropic plant ( $\mathrm{Mi}$ rek, 1984).

Bromus carinatus Hook. and Arn. is an octoploid $(2 n=8 x=56)$ native to the western part of North America. Its range extends to the south as far as the Andes in Columbia. In its native country, it is found from lowland areas up to the subalpine zone. This species can be encountered in well-lit forests and thickets, in prairie communities, but also on meadows and in wasteland (S utkowska and Pasierbiński, 2009). B. carinatus is an annual or perennial plant which flowers from June to September. It grows up to a height of $120 \mathrm{~cm}$ and its culm terminates in a panicle with drooping branches. More than 7 florets are most frequently borne in laterally flattened spikelets. The lemma terminate in a characteristic long awn (5-12 mm) (M irek, 1984). It produces cleistogamous, sometimes also chasmogamous flowers, which reduces allogamy (F a l k ow s ki, 1982). This species has a deep fibrous root system and hence it is drought-resistant. B. carinatus originates from climatic conditions similar to those prevailing in our country, therefore it is no wonder that this plant has quickly settled in Poland as well as in other European countries and it still continues to spread (M i r e k, 1984; P a s i e r b i ń s k i et al. 2005; Pasie rbiński and B łońs ka, 2007; Sutkowska and Pasierbiński, 2009).

The cultivar 'Una' was registered in 1973, ten years after its acclimatization and breeding had been started. In their description of B. unioloides Humb. and Dunth., G ó ral et al. (1987a) report, among others: "Spikelets are 10-flowered with a long awn...", and further: "Awnedness of seeds causes difficulties in mechanical sowing".

In their descriptions, both B. unioloides ( $\mathrm{G}$ ó $\mathrm{r}$ a 1 et al. 1987a) and cv. 'Una' (ChORR, 1985; G ó r a l et al. 1987b) have been reported to be characterized by spikelets with a long awn, which M i r e k (1984) indicates as a trait characteristic of $B$. carinatus, whereas he describes $B$. willdenowii as a plant with an awnless glume or rarely with a very short awn.

The cultivar 'Broma' was derived from cv. 'Una' and it was entered in COBORU's List of Agricultural Plant Varieties in 1988.

\section{MATERIALS AND METHODS}

Material for molecular analysis comprised individuals of the species Bromus carinatus and $B$. willdenowii from the subgenus Ceratochloa, whose seeds came from the USDA collection (Plant Introduction Station, Pullman, USA) (Table 1), as well as individuals of cv. 'Broma' derived from seeds obtained from the company Poznańska Hodowla Roślin Sp. z o.o. Fully developed, healthy (not infected by pathogens and without feeding traces) leaf blades were used for DNA isolation. DNA was isolated using DNAzol Reagent (Invitrogen) in accordance with the protocol given by the manufacturer.

Following DNA isolation, additional DNA purification was carried out by low melting point agarose gel electrophoresis (Invitrogen) in order to remove any impurities that might hinder or prevent DNA amplification. After the separation was completed, the gel was illuminated with UV light, DNA concentration was estimated, and purified DNA blocks were cut out.

ISSR multilocus molecular markers were used in the investigations; they enable polymorphism analysis of the length of unique nuclear DNA sequences separating microsatellite sequence blocks (T s u ma $r$ a et al. 1996; S te pansky et al. 1999). Six ISSR primers were used in the molecular analysis (Table 2). Amplification was carried out in $25 \mu \mathrm{l}$ of reaction mixture containing $5 \mu \mathrm{l}$ of properly diluted DNA samples $(100 \mathrm{pg}), 2.50 \mu \mathrm{l}$ of $10 \times$ reaction buffer, $0.75 \mu \mathrm{l}$ of $25 \mathrm{mM} \mathrm{MgCl} 2,2 \mu \mathrm{l}$ of $10 \mathrm{mM} \mathrm{dNTP}, 1 \mu \mathrm{l}$ of (ISSR) primer, $0.2 \mu \mathrm{l}$ of Tag DNA polymerase, and $13.55 \mu \mathrm{l}$ of distilled water. Primer sequences were taken from the paper of Stepansky et al. (1999). The PCR reaction was performed under the following conditions: initial denaturation at $94^{\circ} \mathrm{C}$ for 5 minutes, 35 amplification cycles: denaturation at $94^{\circ} \mathrm{C}$ for 30 seconds, primer annealing at $47^{\circ} \mathrm{C}$ (for ISSR primers 1 and 3 ) or $44^{\circ} \mathrm{C}$ (ISSR 2, 4, 6, and 7) for 30 seconds, polymerization at $72^{\circ} \mathrm{C}$ for 30 seconds. Additional polymerization was carried out at $72^{\circ} \mathrm{C}$ for 7 minutes.

Electrophoretic separations were performed in $1.5 \%$ agarose gel with the addition of ethidium bromide. The images of electrophoretic separations were archived using the gel documentation system Imagemaster VDS (Pharmacia-Amersham) and original computer software Liscap Capture ver. 1.0. 
The results obtained by using ISSR primers 1 , 4, 6 and 7, which revealed differences between the investigated plant groups (polymorphism of PCR products), were selected for statistical analysis.

In the case of the other primers (ISSR 2 and 3 ), the banding patterns of particular individuals did not differ from each other. By using the DNA fragment length marker (GrneRuler100 bp, Fermentas) and computer software GeleScan ver. 1.45 ("Kucharczyk Techniki Elektroforetyczne"), it was possible to determine the length of the PCR products obtained. A 0-1 matrix was constructed by accepting the presence (1) or absence (0) of the PCR product as a trait; this matrix was applied to perform numerical analysis by UPGMA (Unweighted Pair Group Method with Arithmetic Average) using Jaccard's distance (S o k a 1 and $\mathrm{M} \mathrm{i} \mathrm{c} \mathrm{h} \mathrm{e} \mathrm{n} \mathrm{e} \mathrm{r,} \mathrm{1958)} \mathrm{and} \mathrm{multivariate} \mathrm{Correspondence}$ Analysis (CA) (G r e e n a c re, 2007).

\section{RESULTS}

15 individuals of $\mathrm{cv}$. 'Broma', 25 individuals of $B$. carinatus, and 30 individuals of $B$. willdenowi $i$ were subjected to molecular analysis (Table 1). The primers whose products were included in the analysis generated from 10 to 25 PCR products of different length: ISSR
1-25; ISSR 4-10; ISSR 6-21; and ISSR 7-24. The amplification product length was from $140 \mathrm{bp}$ to $870 \mathrm{bp}$.

The conducted analysis allowed the determination of banding patterns characteristic of the Polish cultivar 'Broma' as well as of $B$. carinatus and $B$. willdenowii (Table 3, Fig. 1). The PCR products that draw attention are those of ISSR 4: 260 and $330 \mathrm{bp}$, and ISSR 6: $200 \mathrm{bp}$; they were found in all the individuals investigated. Marker products were also identified; these are products that were found in 100\% of individuals analysed in a given species but did not occur in the other groups of individuals (Table 3 ).

Two clear groups can be seen in the UPGMA-generated dendrogram and in the chart obtained by using CA analysis on the basis of the molecular analysis results (Figs 2, 3). One is composed of $B$. willdenowii, the other one of $B$. carinatus. The first group is divided into two clades, one of which consists of representatives of the populations CTF and CTE, while the other one consists of the populations CTD, CTC, CTB, and CTA belonging to $B$. willdenowii. The second group is also divided into two clades, one of which consists of representatives of the $B$. carinatus populations: CRB, CRC, CRD, and CRE. Cv. 'Broma' is in the second clade, forming a sister group with the CRA population of B. carinatus (Figs 2, 3).

Table 1.

List of samples of Bromus carinatus and B. wildenowii seeds brought from the USDA collection, Plant Introduction Station, Pullman, USA, with their catalogue number and number of individuals analysed.

\begin{tabular}{|c|c|c|c|}
\hline Species & Sample designation & Catalogue number & Number of individuals analysed \\
\hline \multirow[t]{5}{*}{ Bromus carinatus } & CRA & Pl 232202 & 5 \\
\hline & $\mathrm{CRB}$ & Pl 232205 & 2 \\
\hline & $\mathrm{CRC}$ & Pl 232203 & 3 \\
\hline & CRD & Pl 232201 & 2 \\
\hline & CRE & Pl 232204 & 6 \\
\hline \multirow[t]{6}{*}{ Bromus wildenowii } & CTA & Pl 595117 & 5 \\
\hline & СТВ & Pl 595115 & 5 \\
\hline & CTC & P1 595119 & 5 \\
\hline & CTD & P1 595114 & 3 \\
\hline & CTE & 9054971 & 3 \\
\hline & CTF & P1 595116 & 3 \\
\hline
\end{tabular}

Table 2.

ISSR primers used in molecular analysis (according to S te pan sky et al. 1999)

\begin{tabular}{cc}
\hline Primer & Primer sequence \\
\hline ISSR1 & $(\mathrm{TC})_{8} \mathrm{C}$ \\
ISSR2 & $(\mathrm{AG})_{8} \mathrm{~T}$ \\
ISSR3 & $(\mathrm{GGGTG})_{3}$ \\
ISSR4 & $(\mathrm{ATG})_{6}$ \\
ISSR6 & $(\mathrm{AC})_{8} \mathrm{G}$ \\
ISSR7 & $(\mathrm{AC})_{8} \mathrm{~T}$ \\
\hline
\end{tabular}




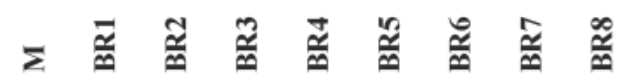

$\mathbf{A}$

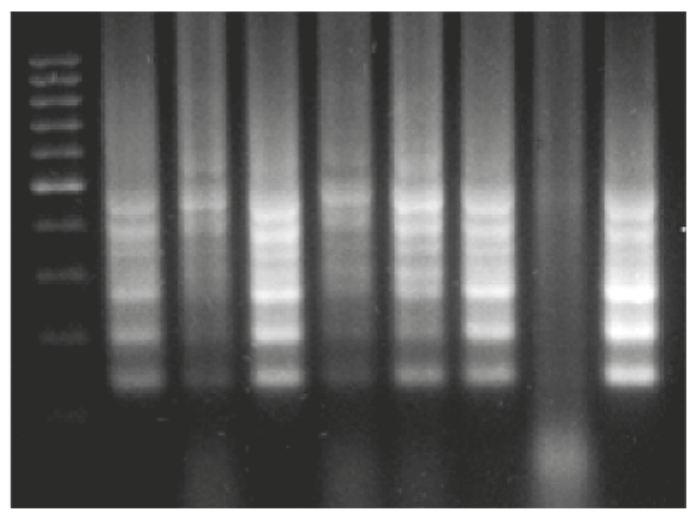

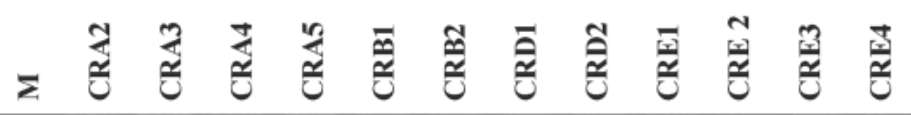

B
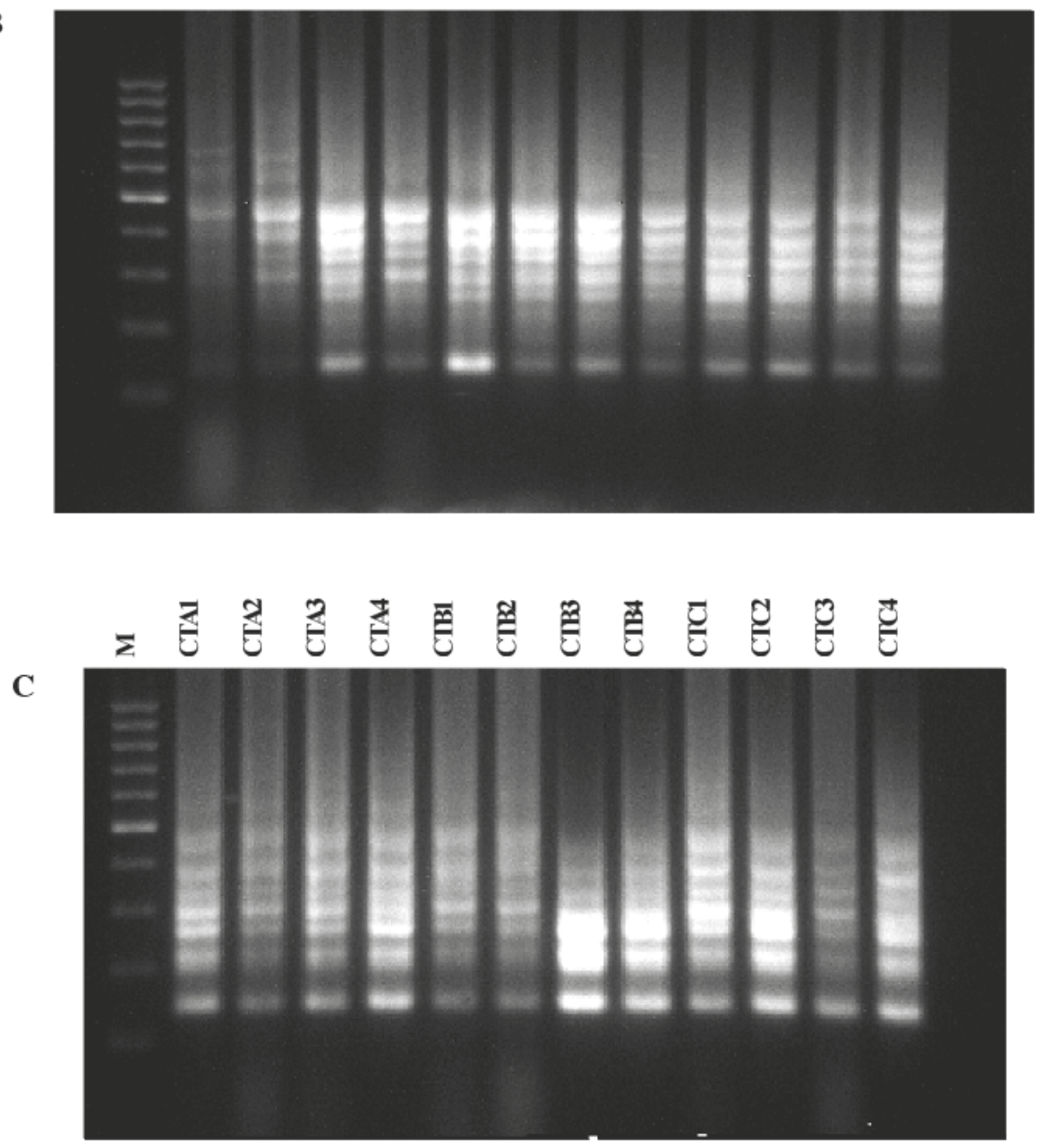

Fig. 1. Example of electrophoretic separation of PCR products generated by using the primer ISSR 6.

A) Cv. 'Broma' - BR1-8;

B) B. carinatus - CRA2-5, CRB1-2, CRD1-2, CRE1-4;

C) B. willdenowii - CTA1-4, CTB1-4, CTC1-4, M - 100bp DNA fragment length marker. 


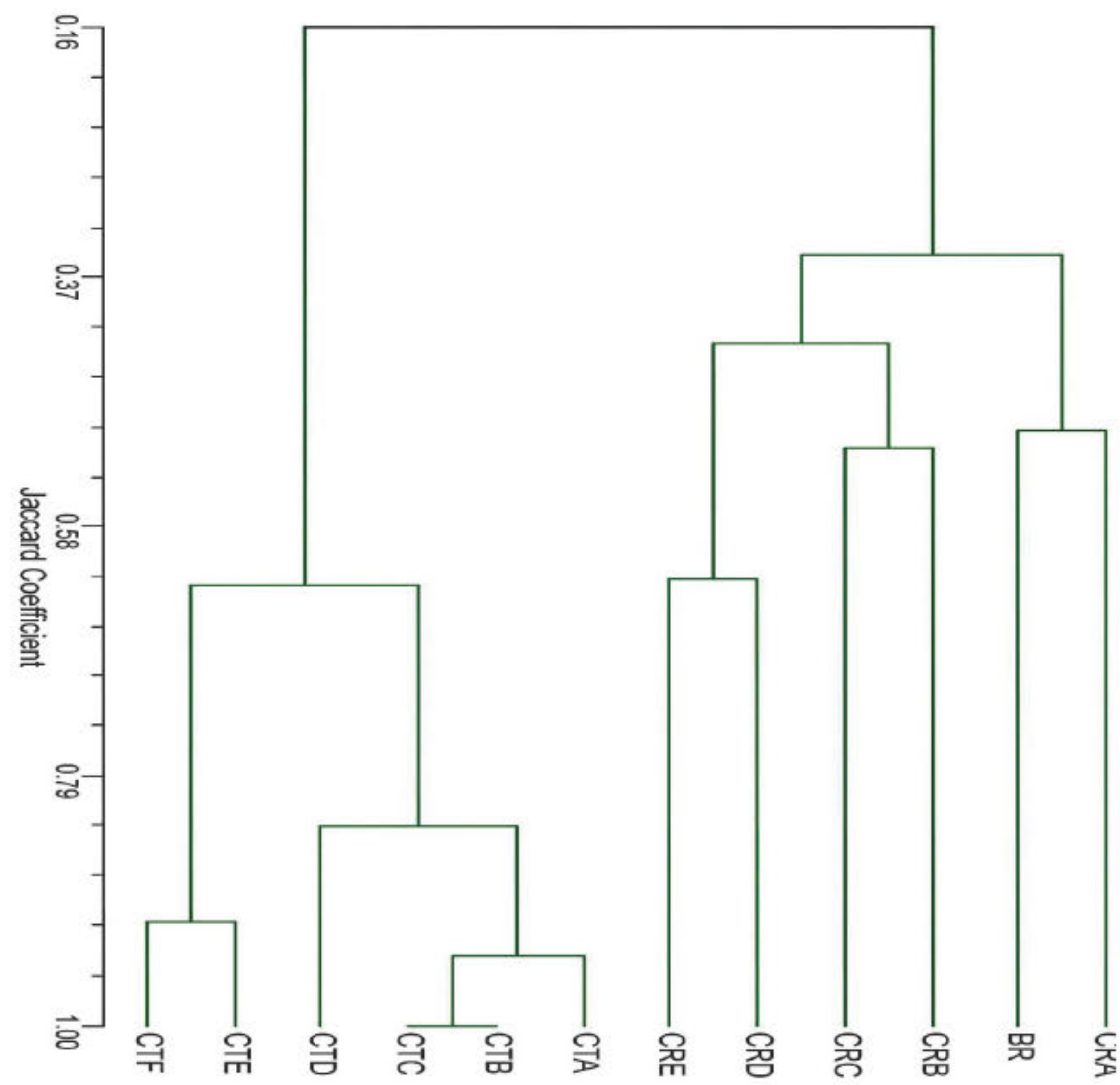

Fig. 2. Numerical analysis of PCR - ISSR products performed by UPGMA: BR - cv. 'Broma'; CRA, CRB, CRC, CRD, CRE B. carinatus; CTA, CTB, CTC, CTD, CTE, CTF - Bromus willdenowii.

\section{CA (Corespondence Analysis)}

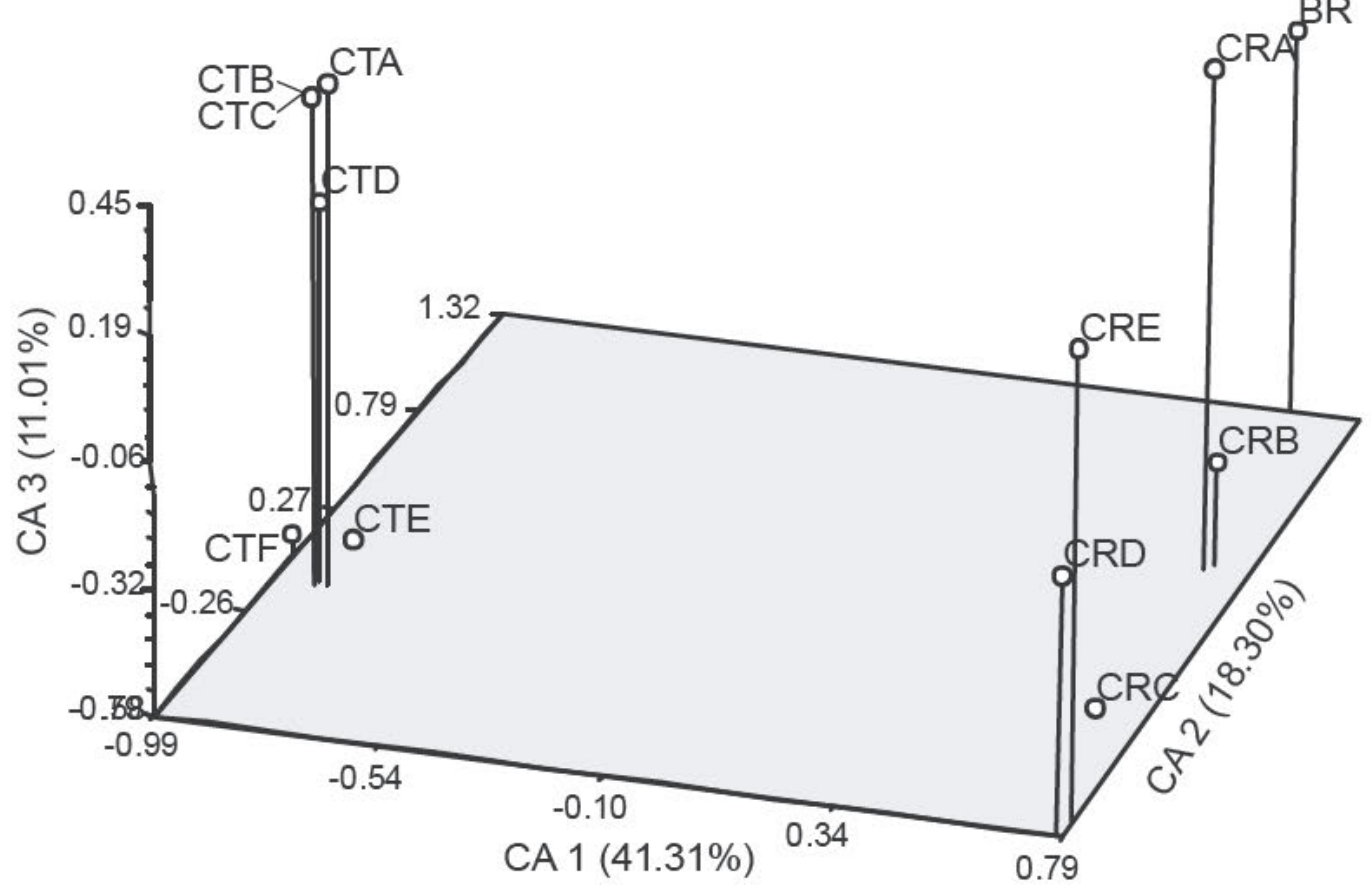

Fig. 3. Numerical analysis of PCR - ISSR products performed by CA: BR - cv. 'Broma'; CRA, CRB, CRC, CRD, CRE B. carinatus; CTA, CTB, CTC, CTD, CTE, CTF - Bromus willdenowii. 
Table 3.

Marker PCR products for B. carinatus, B. willdenowii, and cv. 'Broma'.

\begin{tabular}{|c|c|c|c|c|}
\hline Primer & Length of PCR products & Bromus carinatus & Cv. 'Broma' & Bromus willdenowii \\
\hline \multirow{7}{*}{ ISSR 1} & 240 & \multirow{7}{*}{+} & \multirow{3}{*}{+} & \multirow{4}{*}{+} \\
\hline & 250 & & & \\
\hline & 320 & & & \\
\hline & 330 & & & \\
\hline & 450 & & + & \multirow{3}{*}{+} \\
\hline & 700 & & + & \\
\hline & 780 & & + & \\
\hline \multirow{6}{*}{ ISSR 4} & 210 & + & & \multirow{6}{*}{$\begin{array}{l}+ \\
+ \\
+\end{array}$} \\
\hline & 260 & + & + & \\
\hline & 330 & & + & \\
\hline & 370 & & & \\
\hline & 400 & + & + & \\
\hline & 540 & + & & \\
\hline \multirow{6}{*}{ ISSR 6} & 140 & & & \multirow{6}{*}{$\begin{array}{l}+ \\
+\end{array}$} \\
\hline & 200 & & + & \\
\hline & 370 & & + & \\
\hline & 570 & + & + & \\
\hline & 620 & & + & \\
\hline & 760 & & + & \\
\hline \multirow{5}{*}{ ISSR 7} & 200 & & & \multirow{5}{*}{$\begin{array}{l}+ \\
+ \\
+ \\
+\end{array}$} \\
\hline & 220 & & & \\
\hline & 250 & + & + & \\
\hline & 270 & & & \\
\hline & 360 & + & + & \\
\hline
\end{tabular}

\section{DISCUSSION}

In taxonomic terms, Bromus carinatus is one of the most complicated species of the genus Bromus. In spite of many studies, its knowledge is still insufficient and this species poses many taxonomic and nomenclature problems. The wrong classification of cv. 'Broma' as the taxon $B$. willdenowii illustrates the problems and gaps in systematics that can be encountered within this genus (K u l a, 1999).

In undertaking the present study, a working hypothesis was made which assumed that PCR products obtained would clearly show the affiliation of cv. 'Broma' with the species $B$. carinatus. The arguments in favour of making such an assumption included the distinct morphological differences between $B$. carinatus and $B$. willdenowii described by Mire k (1984), the different ploidy levels of both species, the morphological and cytogenetic similarity between cv. 'Broma' and $B$. carinatus as well as the observations made during a previous molecular study on the spread of B. carinatus in Poland ( $\mathrm{S} \mathrm{u} \mathrm{t} \mathrm{k} \mathrm{ow} \mathrm{ska} \mathrm{and} \mathrm{Pas} \mathrm{i} \mathrm{e} \mathrm{r} \mathrm{-}$ bi ński, 2009).

Nevertheless, the obtained results were not as clear as it had been expected, in spite of the fact that they confirmed the earlier observed absence of variation of cv. 'Broma' and enabled the determination of products specific of the studied taxa.
The molecular analysis performed by using the ISSR-PCR technique determined banding patterns characteristic of cv. 'Broma' as well as of the species $B$. willdenowii and $B$. carinatus originating from the USDA collection. Marker products of the studied taxa were also identified. Products common for cv. 'Broma' and $B$. carinatus as well as PCR products common for cv. Broma, B. carinatus, and B. willdenowii can be distinguished among them. The analysis of the distribution of the markers between the investigated taxa did not allow us to determine unambiguously in which species cv. 'Broma' should be classified. This results from the close affinity of both species, which was noted by P i 1 l a y and Hil u $(1990,1995)$. They found the subgenus Ceratochloa to comprise two complexes: $B$. carinatus and $B$. willdenowii, within which all octoploid and hexaploid species had identical chloroplast DNA sequences (cpDNA). These authors also note that the $B$. willdenowii complex must have been the mother component in natural crossing with diploids of the subgenus Festucaria, as suggested by S t e b b in s and T o b y (1944), which led to the creation of B. carinatus. Analysing also the banding patterns of $B$. carinatus and $B$. willdenowii by $\mathrm{C}$ - banding, high relatedness between these species was shown. Research has identified, among others, six small chromosomes of $B$. carinatus showing affinity with $B$. willdenowii (J o a c h i mi a k et al. 2001). 
However, the conducted numerical analysis suggests that the cultivar 'Broma' should be classified as $B$. carinatus. The dendrogram constructed by UPGMA shows a clear division into two clades. One of them groups $B$. carinatus specimens, while the other one comprises B. willdenowii individuals. Cv. 'Broma' is in the clade of $B$. carinatus, which undoubtedly defines its species affiliation. Thereby, this confirms the results of the earlier morphological study carried out by Mirek (1984) which showed that cv. 'Una' (from which cv. 'Broma' is derived) introduced into cultivation as a fodder cultivar represented in fact $B$. carinatus, not $B$. willdenowii, as mistakenly reported.

It is also worth stressing that although cpDNA analysis conducted by $\mathrm{Pilley}$ and $\mathrm{Hilu}$ (1990 and 1995) has significantly enriched our knowledge on hybridizations taking place in the genus Bromus, in particular the subgenus Ceratochloa, but it has not confirmed the adopted systematic division within this genus. The ISSR-PCR method employed in the present study has made it possible with respect to $B$. carinatus and $B$. willdenowii. The identified markers specific for each species and their clear division into two clades in the numerical analysis prove the divergence of these species.

\section{CONCLUSIONS}

The application of the ISSR method allowed the molecular markers of the studied species to be identified. The numerical analysis of the obtained results suggests that cv. 'Broma' should be classified in the species $B$. carinatus, but this requires confirmation by using additional molecular methods.

\section{Acknowledgements}

I would like to thank warmly Ms. Aleksandra Majerczyk, MA, for making available part of the results of her master's thesis. I thank the USDA Plant Introduction Station, Pullman, USA, for providing $B$. carinatus and B. willdenowii seeds as well as the company Poznańska Hodowla Roślin Sp. z o. o for providing seeds of cv. 'Broma'. I also thank my reviewers for their valuable comments.

\section{REFERENCES}

B or N.L., 1970 Bromus. - [In]: Flora Iranica K. H. Rechinger (ed.), 70: 105-141. Akademische Druck-u. Verlagsanstalt, Graz, Austria.

Charakterystyka Odmian. Rośliny Rolnicze. 1985. Wyd. Centralny Ośrodek Badania Odmian Roślin Uprawnych, Słupia Wielka. (in Polish)

Falkowski M., 1982. Trawy polskie. Państwowe Wydawnictwo Rolnicze i Leśne, Warszawa, 41-61 (in Polish)
Góral S., Królikowski Z., Prończuk S., Prończuk M., Staszewski Z., Święcicki W., 1987a. Stokłosa uniolowata. [In:] Podstawy hodowli, odmianoznawstwa i kwalifikacji polowej roślin uprawnych. S. Prończuk (ed.). Wyd. Instytut Hodowli I Aklimatyzacji Roślin, Radzików: 162-163. (in Polish)

Góral S., Królikowski Z., Prończuk S., Prończuk M., Staszewski Z., Święcicki W., 1987b. Una. [In:] Podstawy hodowli, odmianoznawstwa i kwalifikacji polowej roślin uprawnych. S. Prończuk (ed.). Wyd. Instytut Hodowli I Aklimatyzacji Roślin, Radzików, 164. (in Polish)

Greenacre M., 2007. Correspondence Analysis in Practice, Second Edition. London: Chapman and Hall/CRC.

Joachimiak A, Sutkowska A, Mitka J., 2001. RAPD studies in Bromus (Poaceae) from the Old and New Worlds - preliminary results. Acta Biol. Cracov. Ser. Bot. 43: 79-86.

Ku la A., 1999. Cytogenetic studies in cultivated form of Bromus carinatus (Poaceae). Fragm. Flor. Geobot. Suppl. 7: 101-106.

Lista odmian roślin rolniczych. 1973-2009. Wyd. Centralny Ośrodek Badania Odmian Roślin Uprawnych, Słupia Wielka. (in Polish)

Lista odmian roślin rolniczych. 1989. Wyd. Centralny Ośrodek Badania Odmian Roślin Uprawnych, Słupia Wielka. (in Polish)

Massa A.N., Larson S.R., Jensen K.B., Hole D.J., 2001. AFLP variation in Bromus section Ceratochloa germplasm of Patagonia. Crop Sci. 41:1609-1616.

Massa A.N., Jensen K.B., Larson S.R., Hole D.J., 2004. Morphological variation in Bromus sect. Ceratochloa germplasm of Patagonia. Canad. J. Bot. 82: 136-144.

Mirek Z., 1984. Bromus carinatus Hook. Et Arn. - nowy gatunek synantropijny we florze Polski. / Bromus carinatus Hook. Et Arn. - a new synanthropic species in the flora of Poland. Fragm. Flor. Geobot. 28(2): 97-105. (in Polish)

Opis Odmian Roślin Rolniczych. 1988. Wyd. Centralny Ośrodek Badania Odmian Roślin Uprawnych, Słupia Wielka. (in Polish)

Pasierbiński A., Błońska A., 2007. Ecological and phytosociological spectrum of occurrence of Bromus carinatus Hook. and Arn. in the city of Katowice (Silesian Upland). - [In:] Threats, protection and transformation of vegetation of the Upper Silesia and adjacent areas. S. Wika, G.Woźniak (eds), University of Silesia, Katowice, 105-115.

Pasierbiński A., Woźniak G., Tokarska-Guzik B., 2005. Bromus carinatus in synanthropic communities in the central part of Silesia Upland (S Poland). - [In:] Biology of grasses. L. Frey (ed.) W. Szafer Institute of Botany, Polish Academy of Sciences, Kraków, 335-342.

Pillay M., Hilu K.W., 1990. Chloroplast DNA variation in diploid and polyploid species of Bromus (Poaceae) 
subgenera Festucaria and Ceratochloa. Theor. Appl. Genet. 80: 326-332.

Pillay M., Hilu K.W., 1995. Chloroplast-DNA restriction site analysis in the genus Bromus (Poaceae). Am. J. Bot. 82: 239-249.

Rostański K., Sowa R., 1986-1987. Alphabetical list of the ephemerophytes of Poland. Fragm. Flor. Geobot. 31-32 (1-2): 151-205.

Sokal R.R., Michener C.D., 1958. A statistical method for evaluating systematic relationships. University of Kansas Scientific Bulletin 38: 1409-1438.

Stebbins G.L., 1981. Chromosomes and evolution in the genus Bromus (Gramineae). Bot. Jahrb. Syst. 102: 359-379.

Stebbins G.L., Tobgy H.A., 1944. The cytogenetics of hybrids in Bromus L. Hybrids within the section $\mathrm{Ce}$ ratochloa. Am. J. Bot. 31: 1-11.

Stepansky A., Kovalski I., Perl-Treves R., 1999. Intraspecific classification of melons (Cucumis melo L.) in view of their phenotypic and molecular variation. Plant Syst. Evol. 271: 313-332.

Sutkowska A., Pasierbiński A., 2009. Pochodzenie spontanicznie rozprzestrzeniającego się gatunku Bromus carinatus (Poaceae) na siedliskach ruderalnych i segetalnych w Polsce. / The origin of spontaneously spreading species Bromus carinatus (Poaceae) on ruderal and segetal sites in Poland. Fragm. Flor. Geobot. Polonica, 16(2): 281-295. (in Polish)

Tsumura Y., Ohba K., Strauss S. H., 1996. Diversity and inheritance of inter-simple sequence repeat polymorphisms in Douglas-fir (Pseudotsuga menziesii) and sugi (Cryptomeria japonica). Theor. Appl. Genet. 92:40-45.

Tsvelev N.N., 1970. Grasses of the Soviet Union. Nauka Publishers. Part 1. 298-343.

Zając A., Zając M., Tokarska-Guzik B., 1998. Kenophtyes in the flora of Poland: list, status and origin. Phytocoenosis, 9(10): 107-116.

\section{Weryfikacja pozycji systematycznej stokłosy spłaszczonej (Bromus carinatus Hook. and Arn., Poaceae), cv 'Broma' na podstawie analizy markerów ISSR.}

\section{Streszczenie}

Broma jest odmianą hodowlaną trawy należącej do gatunku Bromus carinatus. Na listach odmian roślin rolniczych Centralnego Ośrodka Badania Odmian Roślin (COBORU) figuruje ona jako Bromus willdenowii (=B. catharticus, $B$. unioloides) (Lista Odmian Roślin Rolniczych 1989-2009) podczas gdy już w 1984 roku Mirek na podstawie porównawczych badań morfologicznych wykazał, że jest to inny, blisko spokrewniony gatunek $-B$. carinatus.

Celem przeprowadzonych badań była weryfikacja przynależności gatunkowej cv 'Broma'. W przeprowadzonych analizach markerów molekularnych ISSR uwzględniono przedstawicieli cv. 'Broma' oraz $B$. carinatus i $B$. willdenowii.

Zastosowana metoda pozwoliła na identyfikację markerów molekularnych wymienionych taksonów. Analizy numeryczne uzyskanych wyników sugerują, że cv. 'Broma' powinna być zaklasyfikowana do gatunku $B$. carinatus, a nie $B$. willdenowii. 